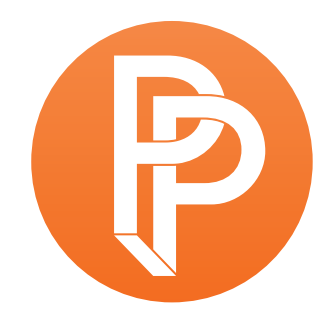

PERFORMANCE

PHILOSOPHY

\title{
READING IMMANENCE
}

\section{ALICE LAGAAY ZEPPELIN UNIVERSITY, FRIEDRICHSHAFEN SUSANNE VALERIE GRANZER UNIVERSITY OF MUSIC AND PERFORMING ARTS VIENNA}

The following text opened the conference, "The Concept of Immanence in Philosophy and the Arts", held in Vienna in May 2016. It is a reader consisting of key passages on immanence by Gilles Deleuze, Baruch de Spinoza, Giorgio Agamben, Henri Bergson, François Laruelle, Antonin Artaud and Friedrich Nietzsche. The reader was put together by Arno Böhler and Elisabeth Schäfer, and a collage of its content arranged by Susanne Valerie Granzer, who read out these text fragments at the start of the conference. Her reading was sporadically interrupted by Alice Lagaay, whose comments served to draw lines of connection between the dense theoretical texts and the performative immanent context in which they were being read and digested-the context of the conference. We present here the readings and their lighthearted-and at times deadly seriouscommentary as performed. Readers are invited to imagine and re-enact the live-ness of this event, letting their own comments, questions and musings interrupt the proposed interruptions of reading.

Listen to this text:

A https://soundcloud.com/performancephilosophy/reading-immanence 
S.V.G.: "Can the entire history of philosophy be presented from the viewpoint of the instituting of a plane of immanence?" (Deleuze 1994a, 44)

"[P]ure immanence requires as a principle the equality of being, or the positing of equal Being: not only is being equal in itself, but it is seen to be equally present in all beings." (Deleuze 1990, 173)

"Being is said in a single and same sense of everything of which it is said, but that of which it is said differs: it is said of difference itself." (Deleuze 1994b, 36)
But seriously, is an institution like the university not necessarily driven, poised towards, and fuelled precisely by the 'other' of immanence?
A. L.: And so it has taken us a good while to get here. An entire history, to "institute" the plane of immanence. Are we there yet? Or is it not always at best a moving towards immanence? (The question of time is one we will no doubt return to). And would we really want to have arrived there? And please excuse my naivety, or the childish unreservedness of this mind that tends to work by means of simple association (as opposed to the logic of pragmatism), but-here it comes-what indeed of the relation between immanence and the institution(s)? Can an institution-like the university, or an academy-ever thrive on immanence?

That's it, I've said it-that was quick! The question now hangs in the air like a lost balloon at a birthday party. It will hover above us, accompany us as we move from room to room. Will it slowly deflate? Or will someone get a stick and pop it? (The laws of physics do still apply to immanence, right?) 
Not the flat ontological plane of facticity, not the equality of beings, but the crystalline promise of the star position, the tip of the pyramid, or at least the imagination thereof, in other words, based on the acceptance of hierarchy? Are there hierarchies within the plane of immanence? (I warned Elisabeth that I was going to have to be bold and unguarded in the expression of my ignorant wonder.)

S.V.G.: "Expression is on the one hand an explication, an unfolding of what expresses itself, the One manifesting itself in the Many [...]. Its multiple expression, on the other hand, involves Unity. The One remains involved in what expresses it, imprinted in what unfolds it, immanent in whatever manifests it [...]." (Deleuze 1990, 16)

S.V.G.: "[Artaud] knows that thinking is not innate, but must be engendered in thought. $\mathrm{He}$ knows that the problem is not to direct or methodically apply a thought which pre-exists in principle and in nature, but to bring into being that which does not yet exist (there is no other work, all the rest is arbitrary, mere decoration)." (Deleuze 1994b, 147)
A.L.: So this is immanence. Not just the reading and debating of discourses on immanence. But the expression-here and now-of the struggle to explain it.

A.L.: "To bring into being that which does not yet exist"... Here we touch on the true serious heart of the P-word. In performance, through performativity, world is not repeated so much as engendered. Which brings me to ask the obvious question, one that I would like us to try and articulate a response to here: How, or in what ways and with what particular consequence, is the question of immanence particularly pertinent to the task of the artist philosopher, or particularly pertinent to the realm of Performance Philosophy? Who can say this? 
S.V.G.: "Perhaps this is the supreme act of philosophy: not so much to think THE plane of immanence as to show that it is there, unthought in every plane, and to think it in this way as the outside and inside of thought, as the not-external outside and the not-internal inside-that which cannot be thought and yet must be thought [...]." (Deleuze 1994a, 59-60)

S.V.G.: "Spinoza was the philosopher who knew full well that immanence was only immanent to itself and therefore that it was a plane traversed by movements of the infinite, filled with intensive ordinates. He is therefore the prince of philosophers." (Deleuze 1994a, 48)

S.V.G.: "Immanence is immanent only to itself and consequently captures everything, absorbs All-One, and leaves nothing remaining to which it could be immanent. In any case, whenever immanence is interpreted as immanent to Something, we can be sure that this Something reintroduces the transcendent." (Deleuze 1994a, 45)
A.L.: Oh boy, I should have done my homework! I should have taken more time to prepare. Now it is what it is. And I don't mean to be facetious, but if only I knew more than I do, if I'd learnt more, worked harder, if I were cleverer, if I'd sat up late for several nights and not just one. Would all that extra knowledge weigh morein terms of immanence-than the pathetic little that my tired mind is able to offer up spontaneously now? Does immanence do away with an ethics of labour? (Or I am barking up the wrong tree, on another plane, planes, lines in the sky-a leitmotiv of my current existence.) My existence? Is who / am and what I bring in terms of experience, or personality, or bewilderment, relevant to the realm of immanence?

A.L.: So much for immanence and hierarchies, she thinks... \& who, may I ask, is the king? 
A.L.: So in order to explore this immanence, we must not place ourselves outside it, there must be no privileged perspective. We are part of it, and everything around us is part of us. Does this mean that in immanence all difference is suspended? And that I can't even appeal to an expert to help explain? (Are there experts in immanence or do we all have equal access? Again: what do I have to do to understand more?)

Reading these fragments of text I have been struck by how hard it is to make sense of fragments, there's a sort of violence at work in having things ripped from their context. And yet at the same time there would seem to be a certain resonance, a certain appropriateness or accordance, between the fragmentary and the immanent. Or is this where a dramatic "suspension of disbelief" is required?

On another note, it has also been noticeable, and worthy of reflection perhaps, that at times there seems to be an immediate way into these texts, they make intuitive sense, yet at other times, it all seems totally opaque and I am locked out. And I have not yet been able to decipher what conditions the difference, the switch; why one moment it all feels so clear, accessible and acceptable, obvious even, but on a different day, in a different mood, there's no way in. Is it a secret language? Or is it like Poe's purloined letter, or Derrida's secret that is not hidden, that is there for everyone to see, whoever knows how not to look, that is. But how to look? That is the question!

S.V.G.: "When immanence is no longer immanent to something other than itself it is possible to speak of a plane of immanence. Such a plane is perhaps a radical empiricism [...]." (Deleuze 1994a, 47) 
A.L.: Radical empiricism, in the sense that it can be perceived by means of the body? But not by my or your or anyone's particular body, correct? For that would make it immanent to something other than itself. Radical empiricism, in the sense that immanence perceives itself, one could almost say, thinks itself... but doesn't that sound very much like Aristotle's unmoved mover, the thought that thinks itself thinking? I fear we're really going to have to try to spell out this central relation between immanence and transcendence. My hunch is that one is not erased so easily by the other, and this immanence that perceives itself and is for no other, where does it leave 'me' in the picture? Or does immanence necessarily go hand in hand with a dissolution of subjectivity? (Who dareth be so bold as to state so?)

S.V.G.: "[Immanence] is the nonthought within thought. It is the base of all planes, immanent to every thinkable plane that does not succeed in thinking it. It is the most intimate within thought and yet the absolute outside-an outside more distant than any external world because it is an inside deeper than any internal world: it is immanence, 'intimacy as the Outside, the exterior become the intrusion that stifles, and the reversal of both the one and the other' [...]." (Deleuze 1994a, 59)

'"Spinoza and us'-this phrase could mean many things, but among other things, it means 'us in the middle of Spinoza.' To try to perceive and to understand Spinoza by way of the middle. Generally one begins with the first principle of a philosopher. But what counts is also the third, the fourth, or the fifth principle.

Everyone knows the first principle of Spinoza: one substance for all the attributes. But we also know the third, fourth, or fifth principle: one Nature for all bodies, one Nature for all

\section{(A.L.: Did I miss the second?)}


individuals, a Nature that is itself an individual varying in an infinite number of ways. What is involved is no longer the affirmation of a single substance, but rather the laying out of a common plane of immanence on which all bodies, all minds, and all individuals are situated. This plane of immanence or consistency is a plan, but not in the sense of a mental design, a project, a program; it is a plan in the geometric sense: a section, an intersection, a diagram.* Thus, to be in the middle of Spinoza is to be on this modal plane, or rather to install oneself on this plane-which implies a mode of living, a way of life. What is this plane and how does one construct it? For at the same it is fully a plane of immanence, and yet it has to be constructed if one is to live in a Spinozist manner.

[* The French word plan, used by the author throughout this chapter, covers virtually all the meanings of the English 'plan' and 'plane.' To preserve the major contrast that Deleuze sets up here, between plan d'immanence ou de consistence and plan de transcendance au d'organisation, I use 'plane' for the first term, where the meaning is, roughly, a conceptualaffective continuum, and 'plan' for the second term. The reader should also keep in mind that 'plan' has the meaning of 'map' in English as well. [trans. note]]" (Deleuze 1988, 122-123)

"It should be clear that the plane of immanence, the plane of Nature that distributes affects, does not make any distinction at all between things that might be called natural and things that might be called artificial. Artifice is fully a part of Nature, since each thing, on the immanent plane of Nature, is defined by the arrangements of motions and affects into which it enters, whether these arrangements are artificial or natural." (Deleuze 1988, 124) 
"Spinoza's ethics has nothing to do with a morality; he conceives it as an ethology, that is, as a composition of fast and slow speeds, of capacities for affecting and being affected on this plane of immanence. That is why Spinoza calls out to us in the way he does: you do not know beforehand what good or bad you are capable of; you do not know beforehand what a body or a mind can do, in a given encounter, a given arrangement, a given combination." (Deleuze 1988, 125)

S.V.G.: "There are two very contrary conceptions of the word 'plan,' or of the idea of a plan, even if these two conceptions blend into one another and we go from one to the other imperceptibly. Any organization that comes from above and refers to a transcendence, be it a hidden one, can be called a theological plan: a design in the mind of a god, but also an evolution in the supposed depths of nature, or a society's organization of power. A plan of this type can be structural or genetic, and both at the same time. It always involves forms and their developments, subjects and their formations. Development of forms and formation of subjects: this is the basic feature of this first type of plan. Thus, it is a plan of organization or development. Whatever one may say, then, it will always be a plan of transcendence that directs forms as well as subjects, and that stays hidden, that is never given, that can only be divined, induced, inferred from what it gives. It always has an additional dimension; it always implies a dimension supplementary to the dimensions of the given.
A.L.: Can't help it, my body and mind are feeling slow tonight. Only hope things will run smoothly tomorrow, hope the adrenalin kicks in, and I can keep up... 
On the contrary, a plane of immanence has no supplementary dimension; the process of composition must be apprehended for itself, through that which it gives, in that which it gives. It is a plan of composition, not a plan of organization or development." (Deleuze 1988, 128)

S.V.G.: "There is no longer a subject, but only individuating affective states of an anonymous force. Here the plan is concerned only with motions and rests, with dynamic affective charges. It will be perceived with that which it makes perceptible to us, as we proceed. We do not live or think or write in the same way on both plans. For example, Goethe, and even Hegel in certain respects, have been considered Spinozists, but they are not really Spinozists, because they never ceased to link the plan to the organization of a Form and to the formation of a Subject. The Spinozists are rather Hölderlin, Kleist, and Nietzsche, because they think in terms of speeds and slownesses, of frozen catatonias and accelerated movements, unformed elements, nonsubjectified affects." (Deleuze 1988, 128129)
A.L.: But how to cut into this language? How to translate it into something that can be shared and negotiated? I can't help feeling a potential fundamentalism at play-is this something we need to be wary of? Is it something we could begin to discuss here? I could play devil's advocate, just to test the waters...

\begin{abstract}
A.L.: Hang on a minute, if you will. Let's take this one step at a time, shall we? (But does it even make sense to speak of 'steps' if we're not really going anywhere, at least not in a teleological sense. Here's a question: Can there be, is there room for the concept of teleology within immanence?)
\end{abstract}


S.V.G.: "The mind can imagine nothing, nor can it recollect past things, except whilst the body endures. Demonstration. The mind does not express the actual existence of its body, nor again does it conceive as actual the affections of the body, except whilst the body endures. [...] Consequently [...], it conceives no body as actually existing except whilst its body endures, and therefore it can imagine nothing [...], nor can it recollect past things, except whilst the body endures [...]." (Spinoza 2000, 302 [book 5, prop. 21])

"For no one so far has had such an accurate knowledge of the structure of the body that he can explain all its functions; to say nothing of the many things that are observed in the lower animals which far exceed human sagacity, and of the fact that sleepwalkers do many things in their sleep that they would not dare to do whilst awake. This shows sufficiently that the body can, by virtue of the laws of its own nature, do many things at which its mind is astonished." (Spinoza 2000, 167 [book 3, prop. 2, schol.])
A.L.: "...except whilst the body endures." And what does it take, or what language would it need, for us to hear, I mean to really hear the message in those words? And do we have the courage to take them in and to respond? And how would it change our every day choices of action? Do we have what it takes, to not just "philosophize", but, in clandestine moments perhaps, to truly acknowledge and share this mortality? For none of this, here, none of this reading, writing, dwelling, thinking together, instituting, none of this is... "except whilst the body endures".

(Really? [she whispers] Are you sure? In those clandestine moments, are you sure?) 
S.V.G.: "The intellectual love of the mind for God is the love by which God loves himself; not in so far as he is infinite, but in so far as he can be explained through the essence of the human mind, considered under a species of eternity; that is, the love of the mind for God is a part of the infinite intellectual love with which God loves himself." (Spinoza 2000, 310 [book 5, prop. 36])

S.V.G.: "This idea which expresses the essence of the body under a species of eternity is, as we have said, a certain mode of thinking which belongs to the essence of the mind, and which is necessarily eternal." (Spinoza 2000, 303 [book 5, prop. 23, schol.])
A.L.: I wonder, has the study of immanence perhaps not so much done away with the idea of God as expanded, broadened, flattened, but how should I put it, in a good sense, "neutralized" the scope of the divine? Is this something we are apt to acknowledge, we here, in this collective, in this context, despite not being theologians and without betraying our..., well our European heritage?

A.L.: [loud] I KNEW we would have to return to the idea of Time! (Didn't I say so?). Here is as good a place as any. I don't mean to trivialize, and, Elisabeth, you are familiar by now with my naivety... but does immanence even allow for time? Or stated otherwise: Isn't the very experience of time, the sense of before and after, of chains of events, of consequences, in other words, of narrative-not to mention drama-isn't the very experience of time, that which leads to notions of beyond (dare I say transcendence)? Can we conceive of temporality whilst holding on to, being in immanence? Or does the practice of immanence (a funny way to put it, I admit, but there's something in it), does the practice of immanence somehow go hand in hand with an 
experience of the dissolution of time? (You know the jargon of here and now, in yoga, in meditation blabla). But where do we stand, we the so-called philosophers of immanence, in relation to the practice of here and now? Can we put our money where our mouths are? Do we dare to philosophize off the cuff, with no agenda, just for the fun of it? And what would have to have gone down beforehand, in terms of preparation, of rehearsal, for this to become a worthy experience? What kind of audience would be so generous as to find it interesting? Or am I mixing my planes again? Again, I don't mean to provoke just for the sake of it, I swear, I really don't!

S.V.G.: "The highest endeavour of the mind, and its highest virtue, is to understand things by the third kind of knowledge. Demonstration. The third kind of knowledge proceeds from an adequate idea of some of the attributes of God to an adequate knowledge of the essence of [particular, addition A. B.] things." (Spinoza 2000, 304 [book 5, prop. 25])

A.L.: So could it be that, for Spinoza, as we progress (if that is indeed what happens), we move from the positing, the saying of God, to the showing, the demonstrating of things, i.e., of particular things? But which particular things? Any things? I can't help but be reminded here of Agamben's announcement at the opening of the Coming Community: "The coming being is whatever being" (Agamben 2009, 1). This sentence has become something of a mantra to me. I love the enigma of it. It's so pregnant with potential. What is this "coming being"? A future being? Is it ever expected to arrive? Is it always only but anticipated? Godot? And if its identity is truly indifferent-anything, whatever, "beliebiges sein"-what is there to love of it? Or to love in it? What justifies the liebe in beliebig...? I sense a secret here, perhaps it holds the key to unraveling some of my many 
questions. Like can there be an ethics of immanence if the plane of immanence is truly neutral; a democracy of things, flat ontology... can there be an ethics of indifference? What might be the basis from which we can call welcome-willkommen heißen-whatever being?

\section{Immanence in Agamben}

S.V.G.: "The principle of immanence, therefore, is nothing other than a generalization of the ontology of univocity, which excludes any transcendence of Being. Yet through Spinoza's idea of an immanent cause in which agent and patient coincide, Being is freed from the risk of inertia and immobility with which the absolutization of univocity threatened it by making Being equal to itself in its every point." (Agamben 1999, 226)

"Immanence flows forth; it always, so to speak, carries a colon with it. Yet this springing forth, far from leaving itself, remains incessantly and vertiginously within itself. This is why Deleuze can state-with an expression that shows his full awareness of the decisive position that immanence would later assume his thoughtthat 'immanence is the very vertigo of philosophy."' (Agamben 1999, 226)
A.L.: Deleuze... Well isn't that just like him? Having flattened things out to the point of making you dizzy.... Come to think of it, perhaps that is the essence of vertigo. Funny, I always thought the feeling was caused by the sense of being up above, by the fear of heights, fear of what it might mean to fall; but no, now I realize, it's just the looking down that makes everything look flat, and that's what the stomach can't take. It's the flatness that causes the vertigo, the sense that everything is equal and relative, the sense that it's all a diagram; the loss, or rather acquisition of perspective. 
Gosh, how terrible it must have felt to have been God!

S.V.G.: "Among the works of Spinoza that have been preserved, there is only one passage in which he makes use of the mother tongue of Sephardi Jews, Ladino. It is a passage in the Compendium grammatices linguae hebraeae in which the philosopher explains the meaning of the reflexive active verb as an expression of an immanent cause, that is, of an action in which agent and patient are one and the same person." (Agamben 1999, 234)

S.V.G.: [On Immanence: A life...]: "In this sense, the colon represents the dislocation of immanence in itself, the opening to an alterity that nevertheless remains absolutely immanent: that is, the movement that Deleuze, playing on Neoplatonic emanation, calls immanation." (Agamben 1999, 223)
A.L.: Je me promène. I walk myself.

Je me lève. I get myself up.

Je m'appelle Alice Mary. I call myself Alice Mary. Ich langeweile mich. I bore myself. Ich erkälte mich. I make myself cold.

A.L.: It's an ominous word though, immanation, don't you think? Resonates with immolation, leading to another transitive verb...

\section{Immanence in Bergson}

S.V.G.: In The Creative Mind, Bergson suggests that to understand a text, we "[...] must fall into step with him [the author] by adopting his gestures, his attitudes, his gait, by which I mean learning to read the text aloud with the proper intonation and inflection. The intelligence will later add shades of meaning. Before intellection properly so-called, there is the perception of structure and movement; there is, on the page one reads, punctuation and rhythm. Now it is in indicating this structure 
and rhythm, in taking into consideration the temporal relations between the various sentences of the paragraph and the various parts of each sentence, in following uninterruptedly the crescendo of thought and feeling to the point musically indicated as the culminating point that the art of diction consists [...]. One knows, one understands only what one can in some measure reinvent." (Bergson 2007, 68-69)
A.L.: One knows, one understands only what one can in some measure re-invent. The intelligence will later add shades of meaning.

\section{Immanence in Laruelle}

S.V.G.: "We call 'posture' the generic a priori dimension of Man. Position and posture are two different ways to take or be a decision. Man is a postural being rather than a positional reason, position indicating an act of transcendence by which he would depart from himself. Phenomenologically, posture seems to be more subjective and global than position, and, from this point of view, the term 'generic' suits the former. It is certainly more real than position-which is always divided and in opposition with others-because posture is immanence before all decision" (Laruelle 2008, 117-120). ${ }^{1}$
A.L.: This reminds me of Roland Barthes' lamentation when it comes to the terror of being asked questions. Like when you're asked to state your opinion, your position on this or that, especially in small-talk at a party. How exhausting it is, he says, to be required to hold a position. How delightful, by contrast, the dream of being allowed to float... So, are we allowed to float? 
S.V.G.: "Existence itself is one idea too many and little by little, softly and brutally, philosophers, savants, doctors and priests are making this life false for us. Really, things are without profundity, there is no beyond or hereafter and no other abyss than this one into which one is put." (Artaud, cited after Dale 2001, 127)
A.L.: Cheer up folks! Don't let the buggers get you down! After exhaustion, comes sleep, after sleep and a good hot drink, comes readiness. Indeed, I would like for us to talk about being ready, to think about what it takes, and about what we are ready for now. Are we prepared for what is to come?

\section{Immanence in Nietzsche}

S.V.G.: "As long as there are philosophers on earth, and wherever there have been philosophers (from India to England, to take the antithetical poles of philosophical endowment), there unquestionably exists a peculiar philosophers' irritation at and rancor against sensuality: Schopenhauer is merely its most eloquent and, if one has ears for this, most ravishing and delightful expression. There also exists a peculiar philosophers' prejudice and affection in favor of the whole ascetic ideal; one should not overlook that. Both, to repeat, pertain to the type; if both are lacking in a philosopher, then-one can be sure of it-he is always only a 'so-called' philosopher." (Nietzsche 1989, 106-107)
A.L.: To be a philosopher, in Nietzsche's eyes, one must refute sensuousness, deny the body and embrace asceticism. His appeal, of course, is for a new kind a philosopher to come, one that would be more in tune with the body, 
S.V.G.: "Ascetic ideals reveal so many bridges to independence that a philosopher is bound to rejoice and clap his hands when he hears the story of all those resolute men who one day said No to all servitude and went into some desert: even supposing they were merely strong asses and quite the reverse of a strong spirit. What, then, is the meaning of the ascetic ideal in the case of a philosopher? My answer is-[...] he does not deny 'existence,' he rather affirms his existence and only his existence, and this perhaps to the point at which he is not far from harboring the impious wish: pereat mundus, fiat philosphia, fiat phiosophus, fiam! [let the world perish, but let philosophy exist, let the philosopher exist, let me exist!]" (Nietzsche 1989, 107-108) more attentive to its inherent wisdom. So, my friends, dare I ask? Where do we stand, we here now, on this topic of asceticism? Where do we stand in relation to the body?

A.L.: [let the world perish, but let philosophy exist, let the philosopher exist, let me exist!] Gathered here, as performance philosophers, do we recognize ourselves in this, do we ascribe to or see ourselves responding to this imperative? In the passion and drive to carry out our work-sometimes at great cost to our own health, not to mention the wellbeing of others. And when we do attune to the body, how much attention do we give it? How well do we listen to it? Sometimes I wonder... what would happen if we entertained the idea that our intellectual work was not a priority in our lives? If the chiastic law of paradox that we so often encounter in these realms (where for instance the 'inner' world discloses itself as actually, unexpectedly corresponding to an 'outer' realm and vice versa), if this paradox testifies to a manifest truth, should we not prepare to lighten our attitude-precisely because we take the work seriously? Throw the 
paper to the wind, let go of the burden of sense-making, I just wonder sometimes...
S.V.G.: "Only now that we behold the ascetic priest do we seriously come to grips with our problem: what is the meaning of the ascetic ideal?-only now does it become 'serious': we are now face to face with the actual representative of seriousness. 'What is the meaning of all seriousness?'-this even more fundamental question may perhaps be trembling on our lips at this point: a question for physiologists, of course, but one which we must still avoid for the moment. The ascetic priest possessed in this ideal not only his faith but also his will, his power, his interest. His right to exist stands or falls with that ideal: no wonder we encounter here a terrible antagonist-supposing we are antagonists of that ideal-one who fights for his existence against those who deny that ideal." (Nietzsche 1989, 116)

"The idea at issue here is the valuation the ascetic priest places on our life: he juxtaposes it (along with what pertains to it: 'nature,' 'world,' the whole sphere of becoming and transitoriness) with a quite different mode of existence which it opposes and excludes, unless it turn against itself, deny itself: in that case, the case of the ascetic life, life counts as a bridge to that other mode of existence. The ascetic treats life as a wrong road on which one must finally walk back to the point where it begins, or as a mistake that is put right by deeds-that we ought to put right: for he demands that one go along with him [...]." (Nietzsche 1989, 117)

"Read from a distant star, the majuscule script of our earthly existence would perhaps lead to the conclusion that the earth was the distinctively ascetic planet, a nook of disgruntled, arrogant, and offensive creatures 
filled with a profound disgust at themselves, at the earth, at all life, who inflict as much pain on themselves as they possibly can out of pleasure in inflicting pain-which is probably their only pleasure. For consider how regularly and universally the ascetic priest appears in almost every age; he belongs to no one race; he prospers everywhere; he emerges from every class of society. [...] It must be a necessity of the first order that again and again promotes the growth and prosperity of this lifeinimical species-it must indeed be in the interest of life itself that such a selfcontradictory type does not die out. For an ascetic life is a self-contradiction: here rules a ressentiment without equal, that of an insatiable instinct and power-will that wants to become master not over something in life but over life itself, over its most profound, powerful, and basic conditions; here an attempt is made to employ force to block up the wells of force; here physiological well-being itself is viewed askance, and especially the outward expression of this well-being, beauty and joy; while pleasure is felt and sought in illconstitutedness, decay, pain, mischance, ugliness, voluntary deprivation, selfmortification, self-flagellation, self-sacrifice. All this is in the highest degree paradoxical: we stand before a discord that wants to be discordant, that enjoys itself in this suffering and even grows more self-confident and triumphant the more its own presupposition, its physiological capacity for life, decreases. 'Triumph in the ultimate agony': the ascetic ideal has always fought under this hyperbolic sign; in this enigma of seduction, in this image of torment and delight, it recognized its brightest light, its salvation, its ultimate victory. Crux, nux, lux - for the ascetic ideal these three are one.-“ (Nietzsche 1989, 117-118) 
A.L.: "I have kept a close eye on the philosophers and read between their lines for long enough to say to myself: the greatest part of conscious thought must still be attributed to instinctive activity, and this is even the case for philosophical thought." (Nietzsche 2002, 6-7) So there.

Notes

1 Passage translated from French into English by Laura Cull Ó Maoilearca and John Ó Maoilearca.

\section{Works Cited}

Agamben, Giorgio. 1999. "Absolute Immanence." In Potentialities, translated by Daniel Heller-Roazen, $220-239$. Stanford University Press: Stanford 1999.

__ - 2009. The Coming Community. Translated by Michael Hardt. Minneapolis and London: University of Minnesota Press.

Bergson, Henry. 2007. The Creative Mind. An Introduction to Metaphysics. Translated by Mabelle L. Andison. New York: Dover Books.

Dale, Catherine. 2001. "Knowing One's Enemy: Deleuze, Artaud, and the Problem of Judgment." In Deleuze and Religion, edited by M. Bryden, 126-137. London: Routledge.

Deleuze, Gilles. 1988. Spinoza. Practical Philosophy. Translated by Robert Hurley. San Francisco: City Lights Books. 1990. Expressionism in Philosophy: Spinoza. Translated by Martin Joughin. New York: Zone Books.

1994a. What is Philosophy? Translated by Hugh Tomlinson and Graham Burchell. New York: Columbia University Press.

1994b. Difference and Repetition. Translated by Paul Patton. New York : Columbia University Press.

Laruelle, François. 2008. Introduction aux sciences géneriques. Paris: Pétra.

Nietzsche, Friedrich. 1989. Genealogy of Morals. Translated by Walter A. Kaufmann. New York: Vintage Books.

1999. Sämtliche Werke. Kritische Studienausgabe in 15 Einzelbänden. Herausgegeben von Giorgio Colli und Mazzino Montinari. 3. Auflage. München/Berlin/New York: DTV Walter de Gruyter [=KSA].

2002. Beyond Good and Evil. Translated by Judith Norman. Oxford and New York: Oxford University Press.

2005. Thus Spoke Zarathustra. Translated by Graham Parkes. Oxford and New York: Oxford University Press.

Spinoza, Baruch de. 2000. Ethics. Translated by G. H. R. Parkinson. Oxford and New York: Oxford University Press. 


\section{Biographies}

Alice Lagaay is currently Interim Professor for Media Theory and Cultural History at Zeppelin University, Friedrichshafen. Her background is in philosophy, her current research focuses on the notion of "creative indifference," and she is actively engaged in the interdisciplinary field of Performance Philosophy. She is a founding member and core convener of the Performance Philosophy international research network, and co-editor (alongside Laura Cull O'Maoilearca and Will Daddario) of the Performance Philosophy book series, published by Palgrave Macmillan. Recent publications in English: "Performance in Philosophy/Philosophy in Performance: How performative practices can enhance and challenge the teaching of theory" (co-authored with Jörg Holkenbrink) in: Performance Matters 2 (1) (2016): 78-85.

Since 1989 Susanne Valerie Granzer has been a Professor of the artistic discipline of the performing arts at the University of Music and Performing Arts Vienna, Max Reinhardt Seminar.

She was trained for being an actress at the MRS in Vienna. Then, for 18 years she had important parts at Theater in der Josefstadt, Volkstheater Wien, Theater Basel, Düsseldorfer Schauspielhaus, Schauspielhaus Frankfurt am Main, Schillertheater Berlin and Burgtheater Wien. Parallel she studied philosophy at Goethe-Universität Frankfurt am Main and the University of Vienna. Doctorate in 1995.

In 1997, together with the philosopher Arno Böhler, she founded wiener kulturwerkstätte GRENZ_film. Many "Philosophy on Stage" lecture performances. Co-founder of BASE (research centre for artistic research und artsbased philosophy, India) and the head of the residence programme there.

FWF research projects (as a cooperation partner): 2005-2007 "Materialität und Zeitlichkeit performativer Sprechakte" (P17600). 2010-2013 „Korporale Performanz/Generating Bodies" (TRP12-G21), 2014-2017 "ArtistPhilosophers. Philosophy AS Arts-based-research" (AR 275-G21). Publications (selection): Schauspieler außer sich. Exponiertheit und performative Kunst, Transcript Verlag, Bielefeld März 2011, second edition 2014. Actors and the Art of Performance. Under Exposure, Palgrave Macmillan 2016.

@ 2017 Alice Lagaay and Susanne Valerie Granzer

c) (i) (2) Except where otherwise noted, this work is licensed under a Creative Commons Attribution-

(c) Non Nommercial-ShareAlike 4.0 International License. 